\title{
A comparative study of visitors to urban, coastal and rural areas. Evidence from the island of Crete
}

\author{
Konstantinos Andriotis ${ }^{1 *}$
}

Received: 08/12/2010 Accepted: 06/03/2011

\footnotetext{
${ }^{1}$ Department of Hotel and Tourism Management, Faculty of Management and Economics, Cyprus University of Technology, P.O.Box.50329, 3603 Lemesos, Cyprus; tel. +357 25002237; fax. +357 2500 2803; e-mail: k.andriotis@cut.ac.cy

* Corresponding author
}

\begin{abstract}
Taking as a case three diverse geographical locations, the coastal resort of Amoudara, the city of Heraklion and the village of Archanes, all of them within the border of the Prefecture of Heraklion on the island of Crete, the aim of this study has been set to provide a better understanding of differences between urban, rural and coastal tourists based on the attributes of the place they visit. Although due to various limitations results cannot be generalized beyond the study population, it was intriguing to find differences in motivations and preferences of urban, rural and coastal tourists which are a consequence of socio-demographic, motivation and travel-related variables. Based on these differences, this study provides implications for future decision making to target specific market segments.
\end{abstract}

(c) 2011 International University College. All rights reserved

Keywords: urban, rural, coastal tourism, behaviour, preferences, motivations, Crete

Citation: Andriotis, K. (2011). A comparative study of visitors to urban, coastal and rural areas.

Evidence from the island of Crete. European Journal of Tourism Research 4(2), pp. 93-108

\section{Introduction}

Destinations serve different roles for tourists (McKercher, Wong and Lau, 2006:647). These roles vary considerably because of differences in tourists' needs and desires and result in the consumption of places in a different way. These behavioural variations induce tourists to choose destinations with certain attributes. As a result, many studies have described aspects of tourists' activity choices in urban, rural and coastal settings (Table 1). According to these studies, tourists visit cities because they serve multiple functions, divided into cultural, sport, shopping and amusement products (Suh and Gartner, 2004); rural locations because of their small scale facilities, unspoilt nature and rural culture (Dernoi, 1991; Opermann, 1996); and coastal resorts for their three S's (sun, sea and sex) offerings (Andriotis, Agiomirgianakis and Mihiotis, 2007). 
Table 1. Destination specific studies

\begin{tabular}{ll}
\hline Setting & Studies \\
\hline Rural & $\begin{array}{l}\text { Chhetri, Arrowsmith and Jackson (2004); Frochot (2005); Holden and Sparrowhawk } \\
\text { (2002); Kastenholz, Davis and Paul (1999); Khan (2003); Sedmak and Mihalic (2008) }\end{array}$ \\
Urban & $\begin{array}{l}\text { Bramwell (1998); Hanson and Hanhon (1981); Heung and Cheng (2000); McKercher, } \\
\text { Wong and Lau (2006); Suh and Gartner (2004) }\end{array}$ \\
Coastal & $\begin{array}{l}\text { Gyte and Phelps (1989); Inbakaran and Jackson (2005); Juaneda and Sastre (1999); } \\
\text { Vaughan and Edwards (1999) }\end{array}$ \\
\hline
\end{tabular}

In studying tourists' preferences and behaviour, researchers have widely used various sociodemographic, geographic and travel-related variables. Although comparative research on variations in the type of destinations and tourists' behaviour can direct destination managers to erroneous marketing and planning decisions, a review of past research provides only a limited understanding of why tourist segments choose specific destinations and respond to each different destination the way they do.

Although mass tourism plays a significant role in the economies of most island destinations (Andriotis, 2004; Hampton and Christensen, 2007; Sheldon, Knox and Lowry, 2005), new market trends have emerged that reduce the importance of this market segment. In particular, changes in modern tourists' values and interests have resulted in the emergence of 'new' types of tourists (Poon, 1998), which resist the homogenizing of coastal resorts and reject inauthentic products developed for mass organised tourism (Gale, 2005; Sedmak and Mihalic, 2008). According to various studies, e.g. Bardolet and Sheldon (2008); Bargeman and van der Poel (2006); Sedmak and Mihalic (2008), modern tourists are more experienced and express increased interest in previously neglected rural and urban destinations. These changes in tourists' preferences as well as the common features of most mature coastal resorts such as loss of uniqueness, ecological degradation, poor product quality, negative image and overdependence on failing markets (Sedmak and Mihalic, 2008:1008), have caused a switch of demand away from classical seaside resorts and have resulted in the emergence of a great variety of destinations.
Thus, it seems necessary to provide detailed information on the different attributes that tourists demand from different locations within an island. By conducting studies which enable destination managers and marketers to understand tourist demand it will become possible to provide alternatives to tourists, which perceive and wish to use the insular space in different ways, by designing products that appeal to a more diversified clientele.

Among island destinations, many Greek islands attract every summer thousands of tourists, mostly from Western Europe. Crete is one of these islands that attracts annually 2.8 million charter tourists, more than $35 \%$ of the national total (HNTO, 2008). The island has remarkable natural, cultural and historical resources (Anagnostopoulou et al, 1996; Andriotis, 2001). Although in the past these tourists combined their visit with culture and nature, nowadays experiencing the cultural and the environmental resources of the island is not always a priority. Today, swimming in the crystal Mediterranean Sea, sunbathing, drinking beer, wine or ouzo, and having fun in a night club are among the main activities of incoming tourists. Thus, the island today attracts mainly package tourists looking for the 3S's offerings (Andriotis, 2001; 2003; 2006a). These tourists tend to visit coastal resorts, and only a small number practice other types of holidays and activities. As a result of the mass type of tourists visiting the island, in 2007, 87.8 percent of tourists arrived between May and September (HNTO, 2008) and 96 percent of accommodation establishments, 95.6 percent of travel agencies, 99 percent of car rentals and all bike rentals were situated on the coast (Andriotis, 2006b). 
In order to verify tourists' choices and activity patterns in settings of different nature, this study compared rural, urban and coastal tourists visiting the same island (Crete) at the same time period. The reason for this was to allow investigation of differences in visitors' background and of possible variations in their motivations and preferences, emerging from the nature of the place they select for their holidays. The rationale for choosing Crete as a case, was that although the island attracts mainly the mass organized market that prefers to visit the coast, modern tourists are becoming more demanding (Gibson and Yiannakis, 2002), and as a result the Cretan tourism industry should respond by diversifying its products. This implies that more research is required on understanding how tourists act in different settings (urban, rural and coastal) within the island in an effort to make the most efficient use of tourism resources and facilities and provide guidelines for future recreational, leisure and infrastructural investments. The article is organized as follows. Following this introduction, section two reviews the literature on decision making and tourist typology. Section three offers an evaluation of the methodology by presenting the data collection and the analysis processes. Section four turns to an analysis of the data collected. The final section provides the conclusions, policy implications and suggestions for future research.

\section{Literature background}

Given the centrality of the decision process to the selection of a destination, tourism consumer behaviour literature comprises a wide range of rigorous conceptual and empirical analyses which describe tourists' destination choice processes. According to many of these studies, e.g. Ankomah, Crompton and Baker (1996); Sirakaya and Woodside (2005); Woodside and Lysonski (1989), the concept of choice sets has been adopted as a central component of the models of tourists' vacation destination selection process. This concept explains that in order to choose a destination, tourists follow a funnellike procedure which starts from a relative large initial set of alternative destinations and through a process of narrowing down, tourists finally select the most promising alternative. However, because of various constraints such as limited information, time available and travel budget, the selection is not always the one that best meets their needs.

Based on the concept of choice sets many studies, e.g. Mayo and Jarvis (1981), view the tourist decision-making as a process consisting of various successive stages. While passing through these stages, the decision-maker is influenced by a multitude of factors. According to Mansfeld (1992) the main factors affecting decision making are functional (or utilitarian), e.g. cost and distance, and emotional, e.g. promotional messages and family and friend influences. In a similar vein, other authors, e.g. Hsu, Tsai and Wu (2009); Sirakaya and Woodside (2005) categorised these factors in two distinct groups consisting of psychological or internal variables such as attitudes, motivations and needs, and non-psychological or external variables such as time, pull factors and marketing mix. In addition to the above, the literature of destination choice (see Table 2) supports that decision making is influenced by individuals' socio-demographic characteristics such as stage in the family life cycle, gender, age, education and income (Debbage, 1991; Zalatan, 1998) and travel-related characteristics such as the type of tourist group and way of booking (Cohen, 1972; Fodness, 1992; Mohsin, 2005; Thornton, Shaw and Williams, 1997). On the other hand, Burch (1969:127-128) believes that "whenever the individual is given the opportunity to avoid his regular routine he will seek a directly opposite activity. Based on this it will be expected that an additional factor in decision-making will be tourists' place of residence, with those residing in urban settings, to seek a rural locale in order to see destinations distinct from their normal place of residence and work and so on. Other studies, e.g. Mayo and Jarvis (1981), assert that tourists' decisions are complex, dynamic and multi-faceted as well as prone to change according to individual circumstances and decision-makers' knowledge. Thus decision making can built on level of previous experience with a destination, and with travel in general as well as information gathered. In the words of Sirakaya and Woodside (2005) more experienced travelers have access to a wider 
A comparative study of visitors to urban, coastal and rural areas. Evidence from the island of Crete.

Table 2. Factors identified and tested by various researchers as explanations of tourists' preferences

\begin{tabular}{|c|c|}
\hline Factros & Studies \\
\hline \multicolumn{2}{|l|}{ Sociodemographics } \\
\hline Gender & $\begin{array}{l}\text { Ekinci, Prokopaki \& Cobanoglou (2003); Hudson (2000); } \\
\text { MacKay \& Fesenmaier (1997) }\end{array}$ \\
\hline Age & $\begin{array}{l}\text { Andriotis, Agiomirgianakis \& Mihiotis (2007); Carr (2006); } \\
\text { Debbage (1991); MacKay \& Fesenmaier (1997); Mykletun, } \\
\text { Crotts \& Mykletun (2001); }\end{array}$ \\
\hline Marital status & MacKay \& Fesenmaier (1997) \\
\hline Income & $\begin{array}{l}\text { Debbage (1991); MacKay \& Fesenmaier (1997); Mykletun, } \\
\text { Crotts \& Mykletun (2001); }\end{array}$ \\
\hline $\begin{array}{l}\text { Occupation/Employment status } \\
\text { Education }\end{array}$ & $\begin{array}{l}\text { Andriotis, Agiomirgianakis \& Mihiotis (2008); Debbage (1991) } \\
\text { Debbage (1991) }\end{array}$ \\
\hline \multicolumn{2}{|l|}{ Arrangement Characteristics } \\
\hline Independent vs. Organised & Britton (1982); Cohen (1972); Husbands (1986) \\
\hline Party size/composition & $\begin{array}{l}\text { Andriotis, Agiomirgianakis \& Mihiotis (2008); Debagge (1991); } \\
\text { Mykletun, Crotts \& Mykletun (2001) }\end{array}$ \\
\hline Previous visits & $\begin{array}{l}\text { Baloglu \& McCleary (1999); Gitelson \& Crompton (1984); } \\
\text { Fakeye \& Crompton (1991); Fallon \& Schofield (2004); Gitelson } \\
\text { \& Crompton (1984); Kemperman, Joh \& Timmermans (2004); } \\
\text { Lau \& McKercher (2004) }\end{array}$ \\
\hline Length of stay & $\begin{array}{l}\text { Andriotis, Agiomirgianakis \& Mihiotis (2008); Debagge (1991); } \\
\text { Uysal, McDonal \& O'Leary (1988) }\end{array}$ \\
\hline Season & $\begin{array}{l}\text { Andriotis, Agiomirgianakis \& Mihiotis (2007); (2008); Kozak \& } \\
\text { Rimmington (1999) }\end{array}$ \\
\hline Type of accommodation used & $\begin{array}{l}\text { Andriotis, Agiomirgianakis \& Mihiotis (2008); Debagge (1991); } \\
\text { Ekinci, Prokopaki \& Cobanoglou (2003) }\end{array}$ \\
\hline Geographic Origin/Nationality & $\begin{array}{l}\text { Andriotis, Agiomirgianakis \& Mihiotis (2007); Hui, Wan \& Ho } \\
\text { (2006); Irwin, Gartner \& Phelps (1990); Juaneda \& Sastre } \\
\text { (1999); Kozak (2001); (2002); Kozak \& Rimmington (2000); } \\
\text { Mykletun, Crotts \& Mykletun (2001); Reid \& Reid (1997) }\end{array}$ \\
\hline
\end{tabular}

range of external information obtained from sources such as internet, travel agencies and brochures, and so they have more travel choices.

For the reason that each destination has unique characteristics, which differentiate it from other destinations, decision making literature, e.g. Crompton and Ankomah (1993); Goossens (2000), recognises the importance of destination attributes in the selection process. According to these studies the criteria that affect the decision making process include pull factors which are all tangible and intangible destination elements that attract tourists to a specific destination and include elements such as climate, distance, prices, nature, local food, host attitudes and quality of services.

While extensive research has been carried out on decision making as a key element of the consumption process, to date little empirical evidence exists to explain the reasons that tourists visit destination with different attributes. Even studies that have been concerned with different types of tourists the majority are either concerned with a single destination (Andriotis, 2009; Bimonte, 2008; Hvenegaard and Dearden, 1998; McKercher, Wong and Lau, 2006); or tend not to refer to any specific case (Cohen, 1972; 1979), or examine the types of a single market segment such as backpackers (Uriely, Yonay and Simchai, 2002) and naturebased tourists (Mehmetoglu, 2005); or are not concerned explicitly with tourists' behaviour, but on issues such as their impacts (e.g. McMinn and Cater, 1998; Smith, 1978); the degree of novelty and familiarity sought (Lepp and Gibson, 2003); and shopping behaviour (Fairhurst, Costello and Holmes, 2007). Among the limited research on differences in the types of tourists, Plog (1973) proposed three main 


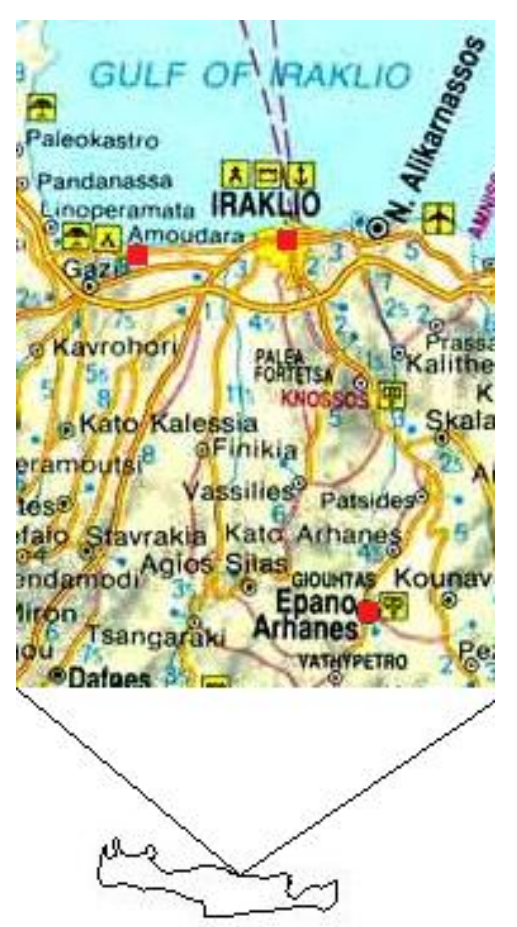

Figure 1. Study locations

types of tourists: the allocentrics (who prefer non-mass tourism destinations and want to discover 'strange cultures'); the psychocentrics (who prefer mass tourist destinations); and the mid-centrics (who are in-between the other two groups); Ceballos-Lascurain (1991) compared mass tourists and eco tourists, and found that although both groups are keen to go to the natural areas, the mass tourists have a more passive role with nature, and participate in activities which do not relate to the true concern over nature or ecology; Loker-Murphy and Pearce (1995) in Australia found that backpackers tend to have more active holidays compared to the other types of visitors; and Bimonte (2008) in Maremma (a coastal area in southern Tuscany, Italy) found that those engaged in nature-oriented activities have different behaviour to those who are involved in beach type holidays. Finally, Yiannakis and Gibson (1992) and Gibson (1994) in their attempt to describe the nature and dimensions of leisure-based tourist created 15 different tourist roles.

\section{Research methodology}

\section{Study setting}

The main sampling criterion of the primary research of this study was to collect data from three different types of tourists visiting the island of Crete on the basis of the location variety of the accommodation they use. In doing so, the research was conducted between June and September 2006, and was focused on three diverse geographical locations, the coastal resort of Amoudara, the city of Heraklion and the village of Archanes, all of them within the border of the Prefecture of Heraklion. Each location is shown in Figure 1 and is briefly described below.

Heraklio is Crete's largest city and administrative center. Built by the sea, the city is the most important commercial port of the island offering to tourists a very good nightlife and many interesting sites to see such as the archaeological museum, the famous Minoan Palace at Knossos, a castle, Venetian buildings, and Byzantine churches. The city's international airport accepts the vast majority of charter tourists arriving on the island (nearly $80 \%$ ). In total, the city has 28 hotels with a capacity of 2,652 beds. Although the city is the largest business and commercial centre of the island and attracts a large number of businessmen, the majority of beds (45\%) are addressed to the low budget segment. According to Lonely Planet (2009), although Heraklion:

is Crete's hectic, noisy and traffic-ridden capital (and) a sprawling modern metropolis of concrete apartment blocks that lacks the architectural charms of Rethymno and Hania (the two other large cities of the island), .... Greece's fifth-largest city has undergone a significant makeover in recent years and is experiencing a period of urban renewal. The waterfront redevelopment has made a marked difference and the city's historic centre has been turned into pleasant pedestrian precinct where its historic monuments are brought to the fore (p.147).

Archanes is a picturesque village, away from the humdrum picture of mass tourism in the coast. Located approximately 15 kilometers 
away from Heraklion, the village has many resources such as archaeological sites, Byzantine temples, natural environment etc, offering to incoming tourists a great variety or activities. The cultural and environmental resources of the village along with its reformation and aesthetic restoration with actions such as the underground installation of electricity, telephone and TV network, and the paving of street, have brought Archanes as one of the most attractive rural destinations in Crete. Nevertheless, the vast majority of tourists visit the village on day trips either by guided bus tours or rented cars, and as a result the village has a small number of bed spaces (in total 108), in three enterprises of rented apartments and four traditional establishments.

Amoudara is one of the coastal resorts of the island located just $6 \mathrm{~km}$ from the city of Heraklion. It presents the common features found in most mature seaside resorts attracting mass organised tourism. Its $7 \mathrm{~km}$ long sandy beach is very well-organized with various types of accommodation establishments, a great selection of shops, beach bars, restaurants, umbrellas to rent and many water sports. In total it has approximately 110 accommodation establishments with approximately 3,600 beds, of which 60 percent are in hotels and the remaining in rented rooms and apartments enterprises.

\section{Sampling Procedure}

In an attempt to collect primary data from a large number of tourists staying in the three study areas, initially sixteen accommodation providers were approached by the researcher, four in the city of Heraklion, four in the coastal resort of Amoudara and eight in Archanes. The larger number of accommodation establishments in Archanes was due to the small bed capacity of accommodation establishments in this location, ranging between four and fourteen rooms or apartments. Following their consent to participate in the study, accommodation providers were given a folder with 100 questionnaires. (In Archanes each folder included only 50 questionnaires because of the small size of accommodation establishments). Accommodation providers were asked to administer the research instrument to one person from each travel party while checking out from their property in such a way that they could complete them on site. Consequently, day-trippers were excluded since all visitors surveyed had to stay at least one night in the lodgings under study.

After frequent attempts it was found that only eight establishments (two in Heraklion, three in Amoudara and three in Archanes) distributed the questionnaires to their guests. From the 650 questionnaires distributed in these establishments (300 in Amoudara, 200 in Heraklion and 150 in Archanes), 221 were collected (34\% of the total). The proportion of questionnaires collected was spread between the three locations as follows: $52 \%$ in Amoudara (115 respondents), $24.4 \%$ in Archanes (54 respondents) and $23.5 \%$ in Heraklion (52 respondents). Attempts to investigate whether the number of questionnaires completed in each location was proportionate to the number of visitors at these locations were unsuccessful due to lack of official statistics. However, based on the fact that the coastal resort and the city of Heraklio had a larger number of bed spaces, it can be concluded that the number of questionnaires completed in each location were not proportionate to each location's number of visitors.

\section{Questionnaire design}

A self-completed questionnaire was designed following a review of past studies such as Gibson and Yannakis (2002); Gibson (1994); as well as past research undertaken in Crete by the author (Andriotis, Agiomirgianakis and Mihiotis, 2007; Andriotis and Agiomirgianakis, 2010). The questionnaire contained three main parts. The first part inquired about visitors' general trip arrangements such as traveling party, length of stay, way of booking and sources of information; and conveyed information about respondents' motivations. The second part gave visitors the opportunity to express frequency of undertaking various activities while on Crete. For each item, tourists were required to indicate the frequency of their behavior on a six-point Likert scale, which included responses ranging from (1) "never", 
(2) "rarely", (3) "sometimes", (4) "often", (5) "very often" to (6) "always". The final part contained questions about respondents' geographic origin and sociodemographic characteristics (gender, marital status, age, education, income and employment status). Following a review of official statistics on the nationalities of tourists visiting Crete, the questionnaire was translated into three languages: English, German and French.

\section{Analytical procedure}

A number of statistical procedures were carried out for this paper using the Statistical Package for the Social Sciences (SPSS) version 14.0.

First, before any statistical analyses were performed, univariate statistics were calculated for all variables. These statistics included frequency distributions, percentages as well as standard deviations and means, where appropriate.

Second, to identify differences between the independent variable location (urban, rural and coastal) and each of the sociodemographic and travel related variables, bivariate statistics were used. Chi-square tests were performed to identify statistically significant relationships between two nominal variables. Cramer's V was calculated in order to identify the strength of the relationship. The main limitation faced in the use of chi-square is that in order to use this test, no more than $20 \%$ of cells should have expected frequencies of less than 5 , and none should contain expected frequencies of less than 1. In instances where any of these happened, the chi-square was used for descriptive reasons, although its validity is questioned. To examine the relationship between two variables, one nominal (location) and one interval (each of the 35 Likert Scale questions dealing with respondents' frequency of undertaking various activities), one-Way Analysis of Variance (ANOVA) was applied. (The level of probability for rejecting the null hypothesis that the independent and dependent variables were not related was .05 for all tests). For open ended (multiple) response questions such as those dealing with respondents motivations, responses were coded into nominal variables and converted into multiple response cross-tabulations. Since there is no statistical test appropriate for multiple response cross-tabulations, it was not possible to statistically test differences in response.

Finally, to identify the main dimensions of tourists' preferences, common factor analysis, with orthogonal rotation, was conducted. The factors were rotated by using the VARIMAX technique. To check the appropriateness of the factor model Kaiser-Meyer-Olkin (KMO) test was used. The KMO measure of sampling adequacy had a value of .791, indicating that both the number of variables and the sample size were appropriate for factor analysis. Finally, the Bartlett's test for sphericity (BTS) was used to examine the hypothesis that the variables are uncorrelated in the population. The result of the BTS test was 3472.765 (df = $595, p=.000$ ), rejecting the null hypothesis that the variables are uncorrelated. To determine the number of factors the criterion of eight values, greater than 1 , were used, and loadings of an absolute value of .45 or more were considered. By using this criterion a total of eight factors were extracted.

\section{Findings and Discussion}

Sociodemographic characteristics

The first step in understanding the sample was to examine respondents' sociodemographic characteristics. The majority of respondents were females $(51.1 \%)$ and married or cohabiting $(76.5 \%)$. In total there were six statistical significant relationships between the sociodemographic characteristics of respondents and the location of the accommodation used (Table 2). First, in line with past research, e.g. Andriotis, Agiomirgianakis and Mihiotis (2008), which supports that age affects holiday preferences, with younger age groups being more likely to have a sense of adventure compared to their older counterparts, the majority of respondents $(66 \%)$ in the city of Heraklion were old (over 56 ), although the majority of those staying in Archanes (42.6\%) were young (between 18 to 35). Second, due to the older age of those staying in the city of Heraklion, the majority $(51 \%)$ were retired or semi/retired, although over than $65 \%$ of those staying in rural and 
Table 3. Profile of respondents

\begin{tabular}{|c|c|c|c|c|c|c|}
\hline Characteristics & $\begin{array}{c}\text { Coastal } \\
\%\end{array}$ & $\begin{array}{c}\text { Urban } \\
\%\end{array}$ & $\begin{array}{c}\text { Rural } \\
\%\end{array}$ & $\begin{array}{c}\text { Total } \\
\%\end{array}$ & $\begin{array}{c}\text { Cramer's } \\
\text { V }\end{array}$ & Sig. ${ }^{\top}$ \\
\hline Gender: & & & & & 0.092 & 0.397 \\
\hline Male & 53.1 & 42.3 & 46.3 & 48.9 & & \\
\hline Female & 46.9 & 57.7 & 53.7 & 51.1 & & \\
\hline Marital status: & & & & & 0.132 & 0.104 \\
\hline Married/Cohabiting & 73.9 & 73.1 & 85.2 & 76.5 & & \\
\hline Single & 20.0 & 13.5 & 13.0 & 16.7 & & \\
\hline Separated/Widowed/Divorced & 6.1 & 13.5 & 1.9 & 6.8 & & \\
\hline Age: & & & & & 0.507 & 0.000 \\
\hline 18-35 years & 29.8 & 16.0 & 42.6 & 29.8 & & \\
\hline $36-45$ years & 26.3 & 10.0 & 33.3 & 24.3 & & \\
\hline $46-55$ years & 25.4 & 8.0 & 14.8 & 18.8 & & \\
\hline $56+$ years & 18.4 & 66.0 & 9.3 & 27.1 & & \\
\hline Geographic Origin: & & & & & 0.610 & 0.000 \\
\hline French & 37.7 & 9.6 & 3.7 & 22.7 & & \\
\hline Netherlands & 8.8 & 0.0 & 59.3 & 19.1 & & \\
\hline German & 17.5 & 9.6 & 14.8 & 15.0 & & \\
\hline American & 2.6 & 48.1 & 1.9 & 13.2 & & \\
\hline Belgium/ Luxembourg & 9.6 & 0.0 & 1.9 & 5.5 & & \\
\hline British & 4.4 & 9.6 & 0.0 & 4.5 & & \\
\hline Other & 19.3 & 23.1 & 18.5 & 20.0 & & \\
\hline Education: & & & & & 0.344 & 0.000 \\
\hline Below high School & 14.3 & 3.9 & 0.0 & 7.8 & & \\
\hline High School & 37.5 & 9.8 & 16.7 & 25.8 & & \\
\hline College/Degree & 36.6 & 35.3 & 31.5 & 35.0 & & \\
\hline Postgraduate and beyond & 12.6 & 51.0 & 51.9 & 30.9 & & \\
\hline Income: & & & & & 0.399 & 0.000 \\
\hline Less than $€ 20.000$ & 22.2 & 4.4 & 8.9 & 14.8 & & \\
\hline Between $€ 20.001-€ 40.000$ & 34.3 & 11.1 & 24.4 & 26.5 & & \\
\hline Between $€ 40.001-€ 60.000$ & 24.2 & 28.9 & 26.7 & 25.9 & & \\
\hline Between $€ 60.001-€ 80.000$ & 11.1 & 24.4 & 13.3 & 14.8 & & \\
\hline$€ 80.001$ or more & 8.1 & 31.1 & 26.7 & 18.0 & & \\
\hline Employment Status: & & & & & 0.332 & 0.000 \\
\hline In full-time employment & 65.2 & 35.3 & 68.5 & 59.1 & & \\
\hline In part-time employment & 8.7 & 11.8 & 20.4 & 12.3 & & \\
\hline Retired/Semi-retired & 13.0 & 51.0 & 7.4 & 20.5 & & \\
\hline Student/Housewife & 13.0 & 2.0 & 3.7 & 8.2 & & \\
\hline Residence: & & & & & 0.241 & 0.000 \\
\hline City & 25.4 & 52.9 & 62.3 & 40.8 & & \\
\hline Town & 42.1 & 31.4 & 24.5 & 35.3 & & \\
\hline Village & 32.5 & 15.7 & 13.2 & 23.9 & & \\
\hline
\end{tabular}

The values shown in bold indicate a statistically relationship at the 0.05 level of confidence

coastal locations were in full time employment. Third, the more affluent and higher educated tourists preferred to stay in urban and rural locations. This finding can be linked to past research, e.g. Debagge (1991); Driver and Tocher (1979), which claims that more educated and higher income tourists tend to be more mobile and to undertake more activities, and as a result they prefer to visit locations such as urban and rural areas, which can offer a more diversified tourism product. Fourth, from the findings it is evident that each location attracted visitors from different geographic origin. In particular, more than one third of respondents $(37.7 \%)$ staying in Amoudara were French; slightly less than half of holidaymakers in Heraklion, Americans; and the majority of those staying in Archanes, 
Table 4. Travel arrangement preferences

\begin{tabular}{|c|c|c|c|c|c|c|}
\hline Preferences & $\begin{array}{c}\text { Coastal } \\
\%\end{array}$ & $\begin{array}{c}\text { Urban } \\
\%\end{array}$ & $\begin{array}{c}\text { Rural } \\
\%\end{array}$ & $\begin{array}{c}\text { Total } \\
\%\end{array}$ & $\begin{array}{c}\text { Cramer's } \\
\text { V }\end{array}$ & Sig. ${ }^{\top}$ \\
\hline $\begin{array}{l}\text { Party composition: } \\
\text { With spouse/partner } \\
\text { With family with children } \\
\text { With a friend/friends } \\
\text { Alone } \\
\text { Other }\end{array}$ & $\begin{array}{c}37.8 \\
53.2 \\
8.1 \\
0.9 \\
0.0 \\
\end{array}$ & $\begin{array}{c}56.3 \\
8.3 \\
8.3 \\
14.6 \\
12.5 \\
\end{array}$ & $\begin{array}{l}58.5 \\
28.3 \\
7.5 \\
1.9 \\
3.8 \\
\end{array}$ & $\begin{array}{l}47.2 \\
36.8 \\
8.0 \\
4.2 \\
3.8 \\
\end{array}$ & 0.503 & 0.000 \\
\hline $\begin{array}{l}\text { Source of information }{ }^{2} \text { : } \\
\text { From friends/word of mouth } \\
\text { From travel brochures/travel agent/Tour } \\
\text { operator } \\
\text { From TV }\end{array}$ & $\begin{array}{l}110.7 \\
78.6 \\
4.5 \\
\end{array}$ & $\begin{array}{l}86.5 \\
78.8 \\
13.5 \\
\end{array}$ & $\begin{array}{l}63.0 \\
46.3 \\
25.9\end{array}$ & $\begin{array}{l}93.1 \\
70.6 \\
11.9 \\
\end{array}$ & & \\
\hline $\begin{array}{l}\text { Way of booking: } \\
\text { Via a package holiday company } \\
\text { Independently (e.g. flight only) } \\
\text { Other }\end{array}$ & $\begin{array}{c}92.8 \\
4.5 \\
2.7\end{array}$ & $\begin{array}{l}61.5 \\
26.9 \\
11.5\end{array}$ & $\begin{array}{l}51.9 \\
33.3 \\
14.8\end{array}$ & $\begin{array}{c}75.1 \\
17.1 \\
7.8\end{array}$ & 0.301 & 0.000 \\
\hline
\end{tabular}

Dutch $(59.3 \%)$. Finally, the majority of urban and rural tourists $(52.9 \%$ and $62.3 \%$ respectively) were residing in a city, although the largest share $(42.1 \%)$ of coastal tourists, were residents of a town.

\section{Travel-related characteristics}

Travel arrangements can differ among tourists visiting destinations offering different tourism products. Table 3 presents respondents' trip arrangement characteristics. In line with the findings of past research that considers Crete as a destination which attracts families (Andriotis, Agiomirgianakis and Mihiotis, 2007; 2008), the majority of the sample were holidaymaking with their spouse or partner $(47.2 \%)$, or with family with children $(36.8 \%)$. The percentage of respondents visiting Crete with spouse or partner was higher for those staying in rural areas, although the majority of those staying in coastal areas (53.2\%) were holidaymaking along with family with children. On the other hand, respondents staying in the city had the lowest percentage of holidaymaking with family with children and the largest percentage of those visiting the place alone, perhaps due to the older age of these visitors. The majority of tourists $(93.1 \%)$ selected Crete on the recommendation of friends and relatives, indicating that word of mouth is the most effective information source for travel decisions to Crete. In addition, recommendation by travel agents and tour operators along with travel brochures was second in priority source of information (70.6\%). As a result, the majority of respondents $(75.1 \%)$ booked their holidays via a package holiday company and only $17.1 \%$ independently, indicating the high dependence of the island on tour operators. As was expected, the percentage of respondents on the coastal resort who booked their holidays via a package holiday company was higher $(92.8 \%)$, compared to those staying in rural locations $(51.9 \%)$, confirming the findings of past research, e.g. Andriotis (2002); (2004) and Andriotis, Agiomirgianakis and Mihiotis (2007), which supports that coastal tourists in Crete tend to buy inclusive tour packages organised exclusively in origin countries.

\section{Motivations}

Motives are internal factors that arouse and integrate tourist behavior and direct tourists to destinations with different attributes (Iso-Ahola, 1980:230; Murray, 1964). For this reason respondents were asked to indicate the main motivational factors that influenced them to choose the specific location for their holidays. As it was expected there were differences on the motivations of different types of tourists. The majority $(72.7 \%)$ of those having chosen to stay in the coastal resort were motivated by the 
sun and good weather, although the main motivation of those staying in the city of Heraklion and the village of Archanes was culture $(75 \%$ and $57.4 \%$ respectively). Surprisingly, the second major motivation of those staying in the coastal resort was to experience the culture, indicating that culture plays also a significant role in the attraction of mass tourists. Third in priority motivation was to get away from everyday life, mainly for visitors to rural and coastal locations $(63 \%$ and $54.5 \%$ respectively). In addition, experiencing the Greek life was more significant for urban and rural tourists $(57.7 \%$ and $51.9 \%$ respectively), having fun and entertainment was a main motivator for coastal tourists (55.5\%) and experiencing nature for all three segments (46.3\%). Finally, cost was the lowest motivation for most respondents $(6.9 \%)$, indicating that respondents did not consider Crete as a cheap destination. This might be a result of the emergence of many cheap destinations in the Mediterranean.

\section{Preferences}

People visit destinations with certain attributes in order to engage in activities that will offer them certain rewards (Driver and Tocher, 1979). However, the rewards from a single activity are not the same for all types of tourists, but they may vary due to the specific offerings of each destination. As shown in Table 5, 28 out of the 35 preference statements presented statistical significant associations. In particular, those staying in urban locations preferred more often cultural and traditional activities as well as educational and societal factors. Relaxation, experiencing the nature and local food and exploring places that are quiet and peaceful as well as avoiding packaged vacations and organized tours, were highly preferred by tourists staying in the rural area, while those staying in the coastal resort preferred more mass type activities such as sunbathing, going out and drinking, and were less likely to experience the culture and to educate themselves. On the other hand, the statements related to sports and adventures were more often preferred by tourists staying in the coast. An exception was the statement "I enjoy the natural landscape" that was higher preferred by tourists staying in rural accommodation.

Table 6 presents the results of the factor analysis. The factor solution used has extracted the eight factors in the order of their importance, with the largest and best combinations first, and then proceeding to smaller. In total, the eight factors explained $65.4 \%$ of the variance. All factors exhibited acceptable alpha levels ranging from 0.895 for the first factor to 0.688 for the third.

The first factor accounts for the largest amount of variance $(23.1 \%)$ and was labelled 'culture' because it was formed by variables assessing respondents' use of various dimensions of each destination's cultural offerings. The second factor explained $10.73 \%$ of the variance, and was labelled 'locality', as this factor was markedly composed of variables related to meeting the local people, learning the local language and culture, and trying the local food.

Table 5. Motivations of respondents

\begin{tabular}{lcccc}
\hline Motive & $\begin{array}{c}\text { Coastal } \\
\%\end{array}$ & $\begin{array}{c}\text { Urban } \\
\%\end{array}$ & $\begin{array}{c}\text { Rural } \\
\%\end{array}$ & $\begin{array}{c}\text { Total } \\
\%\end{array}$ \\
\hline 1. To experience the culture & 58.2 & 75.0 & 57.4 & 62.0 \\
2. To get sunshine, to escape from bad weather & 72.7 & 17.3 & 50.0 & 53.7 \\
3. To get away from everyday life & 54.5 & 17.3 & 63 & 47.7 \\
4. To experience Greek life & 33.6 & 57.7 & 51.9 & 44.0 \\
5. To have fun and entertainment, have a good time & 55.5 & 19.2 & 11.1 & 35.6 \\
6. To experience nature & 27.3 & 23.1 & 46.3 & 31.0 \\
7. To make new friends & 24.5 & 11.5 & 1.9 & 15.7 \\
8. To pursue one's interests & 8.2 & 15.4 & 7.4 & 9.7 \\
9. Cost & 12.7 & 0.0 & 1.9 & 6.9 \\
10. Other & 10.9 & 17.3 & 29.6 & 17.1 \\
\hline
\end{tabular}


Table 6. Overall responses to statements

\begin{tabular}{|c|c|c|c|c|c|c|c|}
\hline & \multicolumn{4}{|c|}{ MEAN } & \multirow[t]{2}{*}{$\mathbf{F}$} & \multirow[t]{2}{*}{ Df } & \multirow[t]{2}{*}{ sig. } \\
\hline & Coastal & Urban & Rural & Total & & & \\
\hline \multicolumn{8}{|l|}{ Natural element and adventure } \\
\hline I enjoy the natural landscape & 4.39 & 4.96 & 5.15 & 4.71 & 10.915 & 212 & 0.000 \\
\hline $\begin{array}{l}\text { I stay physically active engaging in my favourite } \\
\text { sports }\end{array}$ & 2.98 & 2.30 & 2.31 & 2.66 & 6.225 & 208 & 0.002 \\
\hline $\begin{array}{l}\text { I go on adventure travel, such as a trekking } \\
\text { through Samaria Gorge and the like }\end{array}$ & 2.61 & 1.83 & 2.31 & 2.36 & 4.732 & 211 & 0.010 \\
\hline $\begin{array}{l}\text { I participate in activities involving an element of } \\
\text { risk, such as sky diving, rock climbing or ski } \\
\text { jumping }\end{array}$ & 1.89 & 1.20 & 1.37 & 1.61 & 8.817 & 211 & 0.000 \\
\hline \multicolumn{8}{|l|}{ Cultural and traditional element } \\
\hline $\begin{array}{l}\text { I visit archaeological sites, such as Knossos, } \\
\text { Festos, etc. }\end{array}$ & 3.58 & 4.92 & 3.70 & 3.93 & 18.197 & 218 & 0.000 \\
\hline I visit traditional villages & 3.62 & 4.19 & 4.21 & 3.90 & 5.774 & 209 & 0.004 \\
\hline I try to get to know the ways of the local culture & 3.34 & 4.55 & 3.87 & 3.75 & 14.799 & 213 & 0.000 \\
\hline $\begin{array}{l}\text { I visit museums which house archaeological } \\
\text { artifacts from ancient sites and civilizations }\end{array}$ & 3.25 & 4.72 & 3.30 & 3.61 & 22.124 & 212 & 0.000 \\
\hline I visit traditional museums & 3.23 & 4.36 & 3.02 & 3.44 & 15.621 & 213 & 0.000 \\
\hline I visit traditional handicraft laboratories & 2.77 & 3.16 & 2.42 & 2.76 & 3.547 & 206 & 0.031 \\
\hline I visit art galleries & 1.92 & 3.29 & 2.25 & 2.33 & 18.848 & 208 & 0.000 \\
\hline \multicolumn{8}{|l|}{ Imaginary and consumption element } \\
\hline I take photographs & 4.79 & 4.84 & 4.65 & 4.76 & .308 & 216 & 0.736 \\
\hline I buy souvenirs & 3.84 & 3.56 & 2.48 & 3.44 & 21.054 & 215 & 0.000 \\
\hline I buy locally made handicrafts & 3.58 & 3.63 & 2.65 & 3.36 & 12.207 & 216 & 0.000 \\
\hline \multicolumn{8}{|l|}{ Mass tourist element } \\
\hline I visit regular tourist attractions & 3.62 & 3.74 & 2.63 & 3.39 & 15.948 & 210 & 0.000 \\
\hline I sunbathe during the day & 3.60 & 1.64 & 3.37 & 3.12 & 44.900 & 204 & 0.000 \\
\hline I go out every night & 2.91 & 2.94 & 2.52 & 2.82 & 1.711 & 205 & 0.183 \\
\hline I spend most of the day on the beach & 3.06 & 1.68 & 2.17 & 2.53 & 25.847 & 205 & 0.000 \\
\hline I go drinking every night with friends & 1.40 & 1.23 & 1.29 & 2.29 & 12.825 & 200 & 0.000 \\
\hline I do crazy things every night & 1.50 & 1.27 & 1.19 & 1.37 & 3.756 & 198 & 0.025 \\
\hline $\begin{array}{l}\text { I try to meet people of the opposite sex for } \\
\text { uncomplicated romantic experiences }\end{array}$ & 1.30 & 1.11 & 1.06 & 1.20 & 3.437 & 202 & 0.034 \\
\hline \multicolumn{8}{|l|}{ Relaxation element } \\
\hline I relax during the day & 3.96 & 3.00 & 4.15 & 3.80 & 13.688 & 209 & 0.000 \\
\hline I generally avoid the regular tourist route & 2.87 & 3.70 & 4.26 & 3.41 & 25.643 & 204 & 0.000 \\
\hline I avoid packaged vacations and organized tours & 2.75 & 3.45 & 4.65 & 3.38 & 31.044 & 215 & 0.000 \\
\hline $\begin{array}{l}\text { I head for places that are quiet and peaceful, } \\
\text { such as a deserted beach, a cabin in the hills, } \\
\text { and the like }\end{array}$ & 2.91 & 2.98 & 4.09 & 3.23 & 15.546 & 207 & 0.000 \\
\hline \multicolumn{8}{|l|}{ Education and social element } \\
\hline I enjoy trying the local food & 4.44 & 4.92 & 4.94 & 4.67 & 4.768 & 214 & 0.009 \\
\hline I try to mingle with the locals whenever possible & 3.13 & 3.79 & 3.64 & 3.41 & 5.658 & 210 & 0.004 \\
\hline I try to learn the Greek language & 2.84 & 3.72 & 3.08 & 3.11 & 7.051 & 205 & 0.001 \\
\hline $\begin{array}{l}\text { I undertake educationally oriented activities in } \\
\text { Crete that enable me to study and/or acquire } \\
\text { new skills and knowledge }\end{array}$ & 1.94 & 2.70 & 1.47 & 1.99 & 11.059 & 208 & 0.000 \\
\hline I enjoy meeting the local people & 3.21 & 3.85 & 3.79 & 3.50 & 5.521 & 205 & 0.005 \\
\hline I explore the meaning of life & 3.04 & 3.24 & 2.98 & 3.07 & 0.442 & 206 & 0.643 \\
\hline I try to learn about myself & 2.87 & 2.98 & 2.98 & 2.92 & 0.161 & 201 & 0.851 \\
\hline I dine at the best restaurants & 2.75 & 3.24 & 2.94 & 2.92 & 2.594 & 200 & 0.077 \\
\hline $\begin{array}{l}\text { I participate in planned study programs which } \\
\text { included lectures, workshops, and the like }\end{array}$ & 1.82 & 2.70 & 1.43 & 1.91 & 11.757 & 209 & 0.000 \\
\hline I visit friends and relatives & 1.58 & 1.64 & 1.42 & 1.55 & 0.528 & 203 & 0.591 \\
\hline
\end{tabular}


The third factor, explained $8 \%$ of the variance and was labelled 'entertainment' for the reason that all five variables loading in this factor were related to various aspects of entertainment such as going out, drinking and meeting people. The remaining five factors accounted for a relatively small proportion of variability $(23.5 \%)$ and were labelled based on the characteristics of their composing variables. Among them, it is noteworthy that the sixth factor (mass tourism) has the variable with the highest loading (0.868) for the statement "I sunbathe during the day". Also the other two sentences found in this factor had high loadings (0.756 and 0.754$)$ indicating the high interrelationship of the variables in this factor.

\section{Conclusion}

Up to now tourism development in Crete was directed to the attraction of more tourists through the increase of the number of beds in the coast, rather than trying to provide diversified products and services to meet tourists' diversified needs and desires (Andriotis, 2002; 2003; 2005). As a result of past policy-making, today the island of Crete is visited mainly by low spending mass tourists concentrated in space and time. This has resulted in the concentration of the island's population in the north coast and coastal resorts, where the majority of tourism enterprises are located (Andriotis, 2006b). As a solution to the low spending power of incoming tourists, the seasonality of tourist arrivals and the regional concentration of tourism activity, the attraction of tourists, other that the mass organized market, is required. In achieving this, policy-makers and entrepreneurs should be aware of the preferences of individual market segments. Only then, they will be able to design additional, or improve existing products which will attract market attention.

To overcome past research negligence, this study attempted to contribute to the further understanding of tourists' visiting coastal, urban and rural locations of the island of Crete by employing an empirical approach to aspects of tourists' profiles, motivations and preferences. The findings of this study demonstrated the existence of many differences between the three types of tourists. These differences are summarised below, and are being used as a guide to provide implications for future decision-making.

First, tourists staying in the city of Heraklion were more likely to be old and retired or semi/retired, almost half of them, originated from United States, having high education qualifications and their residence in a city, and were on vacation along with their spouse/partner. They were primarily motivated by their interest in culture and Greek life, and as a consequence they preferred to undertake cultural and educational activities. Since these individuals were culture-oriented, they may provide a good market for the city of Heraklion to position itself as a cultural destination, under the condition that investment of funds for the development and promotion of the heritage and historic sites is undertaken. In terms of infrastructure, since many tourists in this segment were senior citizens, and according to the forecasts the proportion of senior citizens is steadily growing (Tretheway and Mak, 2006), there is a need to manage the city's infrastructure in such a way to provide comfortable accommodation, transportation and shopping facilities for senior tourists.

Second, respondents staying in the rural area of Archanes tended to be younger, highly educated, in full time employment and affluent, and the majority originated from the Netherlands. They were residing in a city, and were visiting the destination with their spouse or partner in order to relax and experience the nature, culture, Greek life and local food of the quiet and peaceful village. Since these tourists exhibited a higher exploratory behaviour and avoided organized tours in order to attract this market segment, the destination has to offer targeted products that emphasize the exploration aspects of the vacation and the environmental and cultural resources of the place. At the destination level, these tourists do not necessarily require large scale facilities. Instead, smaller traditional facilities can be offered to support the local economy.

Third, coastal tourists who visited Amoudara typically were the least educated, the majority were employed full time, lived in towns and had 
a lower income. They visited Crete with family with children, they were more likely to purchase package tours, and were motivated by the sun, the good weather and the entertainment opportunities of the place. As a result they preferred passive type of activities such as sunbathing, going out and drinking. According to past research, e.g. Andriotis (2008); Debagge (1991); Hills and Lundgren (1977), when mass travelers, as those in this group, arrive at large resorts and self contained hotels spend only a limited time to areas outside the resort. Thus the aim of future policymaking should be to provide facilities within the resort (shopping, recreational, sport, leisure and gambling) that will encourage them to increase their spending.

This paper is a destination specific study that made possible to identify whether tourists' preferences differ due to the type of the location they visit. Although the study revealed considerable differences within the three study groups, the findings were constrained by the limitation imposed by the inclusion of only three locations of the island of Crete. Therefore, it may be useful to extend further this research by conducting surveys on other Cretan locations in order to provide propositions on common characteristics between resorts within the island, something that will make possible the suggestion of policy implications for specific locations of the island. In addition, this study was focused only on tourists visiting a Mediterranean island destination. Since hardly any studies of tourists' preferences have been undertaken in relation to the types of tourists in other islands, it was not possible to compare the findings of this study to other pieces of research in order to provide implications and draw lessons for other destinations with similar characteristics. On the other hand, as the primary research was carried out only during the summer season, some market segments such as business travellers might have not been researched, simply because they were not there at the time. In order to obtain results that could be generalized and to enhance their reliability, it may be useful to extend further this research by conducting surveys on other island destinations and different periods of year. In doing so, it will become possible to identify whether differences and similarities exist between destinations, before any definite statements can be made about tourists' preferences.

To conclude, gaining feedback from tourists of various forms by measuring how well different types of destinations are doing can provide guidelines to tourism planners and marketers on how to improve the offered product and services create a positive image and increase the likelihood of return (Milman and Pizam, 1995). This study was among the first attempts to provide a better understanding of differences between urban, rural and coastal tourists based on the attributes of the place they visit on the island of Crete. Inevitably, this attempt faces various limitations, such as limited time, low budget, and refusal of a significant number of accommodation establishments to participate in the survey. Thus, the sample might not necessarily represent all foreign tourists in the areas under study. As a result, the findings of this study results cannot be generalized beyond the study population. Nevertheless, the major findings of this study can have significant implications for island destinations wishing to attract different types of tourists by providing diversified tourism products.

\section{Acknowledgement}

The author would like to thank the Greek Foundation of State Scholarships for funding this survey.

\section{References}

Anagnostopoulou K, Arapis T, Bouchy I, Micha I. (1996). Tourism and the Structural Funds - The Case for Environmental Integration. Athens: RSPB.

Andriotis K. (2001). Tourism planning and development in Crete. Recent tourism policies and their efficacy. Journal of Sustainable Tourism, 9(4), 298-316.

Andriotis K. (2002). Dependency on tour operators. Problem faced by the Cretan tourism businesses and the views of their owners/managers. International Journal of Hospitality and Tourism Administration, 4(3), 23-48.

Andriotis K. (2003). Tourism in Crete. A form of modernisation. Current Issues in Tourism, 6(1), 23-53. 
Andriotis K. (2004). Problems of island tourism development: The Greek insular regions. In: Bramwell, B. (ed). Coastal Mass Tourism: Diversification and Sustainable Development in Southern Europe. Clevedon: Channel View Publications, pp. 114-132.

Andriotis K. (2005). Community groups' perceptions and preferences to tourism development: Evidence from Crete. Journal of Hospitality and Tourism Research, 29(1), 67-90.

Andriotis K. (2006a). Host, guests and politics Coastal resorts morphological change. Annals of Tourism Research, 33(4), 1079-1098.

Andriotis K. (2006b). Researching the development gap between the hinterland and the coast - Evidence from the Island of Crete. Tourism Management, 27(4), 629-639.

Andriotis K. (2008). Integrated resort development - The case of Cavo Sidero, Crete. Journal of Sustainable Tourism, 16(4): 428-444.

Andriotis K. (2009). Sacred Site Experience - A Phenomenological Study. Annals of Tourism Research, 36(1), 64-84.

Andriotis K, Agiomirgianakis G, Mihiotis A. (2007). Tourist vacation preferences - The case of mass tourists to Crete. Tourism Analysis, 12(1/2), 51-63.

Andriotis K, Agiomirgianakis G, Mihiotis A. (2008). Tourist satisfaction - A factor-cluster segmentation approach. Journal of Vacation Marketing, 14(3), 221-235.

Andriotis K., Agiomirgianakis G. (2010) Cruise Visitors' Experience in a Mediterranean Port of Call. International Journal of Tourism Research, 12(4), 390-404.

Ankomah, P.K, Crompton, J. L, Baker, D. (1996). Influence of cognitive distance in vacation choice. Annals of Tourism Research, 23(1), 138-150.

Bardolet, E, Sheldon, P.J. (2008). Tourism in archipelagos: Hawai'i and the Balearics. Annals of Tourism Research, 35(4), 900923.

Bargeman, B, van der Poel, H. (2006). The role of routines in the vacation decision-making process of Dutch vacationers. Tourism Management, 27, 707-720.

Bimonte S. (2008). Park visitors vs. beach tourists: A comparative study in an Italian coastal region. European Journal of Tourism Research, 1(2), 112-127.

Bramwell B. (1998). User satisfaction and product development in urban tourism. Tourism Management, 19(1), 35-48.

Burch, W. R. (1969). The social circles of leisure: Competing explanations. Journal of Leisure Research, 1(2), 125-147.

Ceballos-Lascurain, H. (1991). Tourism, ecotourism and protected areas. Parks, 2(3), 31-35.

Chhetri, P., Arrowsmith, C., Jackson, M. (2004). Determining hiking experiences in nature-based tourist destinations. Tourism Management, 25, 31-43.

Cohen, E. (1972). Toward a sociology of international tourism. Social Research, 39, 164-182.

Cohen, E. (1979). A phenomenology of tourist types. Sociology, 13, 179-201.

Crompton, J. L, Ankomah, P. K. (1993). Choice set propositions in destination decision. Annals of Tourism Research, 20(3), 461476.

Debagge, K. G. (1991). Spatial behavior in a Bahamian resort. Annals of Tourism Research, 18, 251-268.

Dernoi, L. A. (1991). About rural and farm tourism. Tourism Recreation Research, 16(1), 3-6.

Driver, B., Tocher, S. R. (1979). Toward a behavioural interpretation of recreational engagements with implications for planning. In: van Doren et al. (eds.), Land and Leisure, Concepts and Methods in Outdoor Recreation. London: Metheun, pp. 86-104.

Fairhurst, A., Costello, C., Holmes, A. F. (2007). An examination of shopping behavior of visitors to Tennessee according to tourist typologies. Journal of Vacation Marketing, 13, 311 - 320.

Fodness, D. (1992). The impact of family life cycle on the vacation decision making process. Journal of Travel Research, 2(2) 8-13.

Frochot, I. (2005). A benefit segmentation of tourists in rural areas: A Scottish perspective. Tourism Management, 26, 335-346.

Gale, T. (2005). Modernism, Post-modernism and the decline of British seaside resorts as long holiday destinations: A case study of Rhyl, North Wales. Tourism Geographies, 7, 86-112. 
Gibson, H. (1994). Some Predictors of Tourist Role Preference for Men and Women over the Adult Life Course. PhD dissertation. University of Connecticut.

Gibson, H., Yiannakis, A. (2002). Tourist roles, needs and the life course. Annals of Tourism Research, 29, 358-383.

Goossens, C. (2000). Tourism information and pleasure motivation. Annals of Tourism Research, 27, 301-321.

Gyte, D. M., Phelps, A. (1989). Patterns of destination repeat business: British tourist in Mallocra, Spain. Journal of Travel Research, 28(1), 24-28.

Hampton, M, Christensen, J. (2007). Competing industries in islands: A new tourism approach. Annals of Tourism Research, 34, 998-1020.

Hanson, S., Hanhon, P. (1981). The travel-activity patterns of urban residents: dimensions and relationships to socio-demographic characteristics. Economic Geography, 57(4), 332-347.

Heung, V. C. S., Cheng, E. (2000). Assessing tourists' satisfaction with shopping in the Hong Kong special administrative region of China. Journal of Travel Research, 38, 396-404.

Hills, T. L., Lundgren, J. (1977). The impact of tourism in the Caribbean: a methodological study. Annals of Tourism Research, 4(5), 248-267.

HNTO 2008. Statistics. Athens: Hellenic National Tourism Organisation.

Holden, A., Sparrowhawk, J. (2002). Understanding the motivations of ecotourists: the case of trekkers in Annapurna, Nepal. International Journal of Tourism Research, 4, 435-446.

Hsu, T., Tsai, Y., Wu, H. (2009). The preference analysis for tourist choice of destination: A case study of Taiwan. Tourism Management, 30, 288-297.

Hvenegaard, G. T., Dearden, P. (1998). Ecotourism versus tourism in a Thai National Park. Annals of Tourism Research, 25(3), 700-720.

Juaneda, C., Sastre, F. (1999). Balearic islands tourism: a case study in demographic segmentation. Tourism Management, 20(4), 549-552.

Inbakaran, R., Jackson, M. (2005). Understanding resort visitors through segmentation. Tourism and Hospitality Research, 6(1), 53-71.
Iso-Ahola, E. (1980). The Social Psychology of Leisure and Recreation. Wm. C. Brown Company, Dubuque, IA.

Kastenholz, E., Davis, D., Paul, G. (1999). Segmenting tourists in rural areas: the case of North and Central Portugal. Journal of Travel Research, 37, 353-363.

Khan, M. (2003). Ecotourists' quality expectations. Annals of Tourism Research, 30(1), 109-121.

Lepp, A., Gibson, H. (2003). Tourist roles, perceived risk and international tourism. Annals of Tourism Research, 30(3), 606624.

Loker-Murphy, L, Pearce, P. L. (1995). Young budget travelers: backpackers in Australia. Annals of Tourism Research, 22(4), 819-843.

Lonely Planet (2009). Heraklion. URL: http://www.lonelyplanet.com/shop_pickan $\mathrm{dmix} /$ previews/crete-4-iraklio-preview.pdf (Accessed on 04/05/2009).

Mansfeld, Y. (1992). From motivation to actual travel. Annals of Tourism Research, 19(3), 399-419.

Mayo, E. J., Jarvis, L. P. (1981). The psychology of leisure travel. Boston, MA: CBI Publishing Company, Inc.

McKercher, B., Wong, C., Lau, G. (2006). How tourists consume a destination. Journal of Business Research, 59(5), 647-652.

McMinn, S., Cater, E. (1998). Tourist typology: observations from Belize. Annals of Tourism Research, 25, 675-699.

Mehmetoglu, M. (2005). A case study of naturebased tourists: Specialists versus generalists. Journal of Vacation Marketing, 11(4), 357-369.

Milman, A., Pizam, A. (1995). The role of awareness and familiarity with a destination: the Central Florida case. Journal of Travel Research, 33(3), 21-27.

Mohsin, A. (2005). Tourist attitudes and destination marketing - the case of Australia's Northern Territory and Malaysia. Tourism Management, 26, 723-732.

Murray, E. J. (1964). Motivation and Emotion. Englewood Cliffs: Prentice Hall.

Opermann, M. (1996). Rural tourism in Southern Germany. Annals of Tourism Research, 23(1), 86-102.

Plog, S. (1973). Why destination areas rise and fall in popularity? The Cornell Hotel and 
Restaurant Administration Quarterly, 14(3), 13-16.

Poon, A. (1998). Tourism, Technology and Competitive Strategies. Oxon: CABI Publishing.

Sedmak, G., Mihalic, T. (2008). Authenticity in mature seaside resorts. Annals of Tourism Research, 35(4), 1007-1031.

Sheldon, P., Knox, J., Lowry, K. (2005). Sustainability in a mature mass-tourism destination: The case of Hawai'i. Tourism Review International, 9, 47-60.

Sirakaya, E., Woodside, A. G. (2005). Building and testing theories of decision making by travelers. Tourism Management, 26, 815-832.

Smith, V. L. (1978). Hosts and Guests: The Anthropology of Tourism. Oxford: Blackwell.

Suh, Y. K., Gartner, W. C. (2004). Perceptions in international urban tourism: an analysis of travelers to Seoul, Korea. Journal of Travel Research, 43, 39-45.

Thornton, P. R., Shaw, G., Williams, A. M. (1997). Tourist group holiday decision making and behavior: The influence of children. Tourism Management, 18(5), 287-297.

Tretheway, M., Mak, D. (2006). Emerging tourism markets: Ageing and developing economies. Journal of Air Transport Management, 12(1), 21-27.

Uriely, N., Yonay, Y., Simchai, D. (2002). Backpacking experiences: A type and form analysis. Annals of Tourism Research, 29(2), 520-538.

Vaughan, D. R., Edwards, J. R. (1999). Experiential perceptions of two winter sun destinations: The Algarve and Cyprus. Journal of Vacation Marketing, 5(4), 356-368.

Woodside, A. G, Lysonski, S. (1989). A general model of traveler destination choice. Journal of Travel Research, 27(1), 8-14.

Yiannakis, A., Gibson, H. (1992). Roles tourists play. Annals of Tourism Research, 19, 287-303.

Zalatan, A. (1998). Wives' involvement in tourism decision process. Annals of Tourism Research, 25(4), 890-903. 